\title{
Antecedent Capital Structure and Its Effect on FirmValue : Case Study on Tourism Industry Sector Listed in Indonesia Stock Exchange
}

\author{
Ngatemin \\ Department of Accounting \\ Universitas Sumatera Utara \\ Medan, Indonesia \\ ngnngatemin@gmail.com
}

Erlina

Department of Accounting

Universitas Sumatera Utara

Medan, Indonesia

Erlina@usu.ac.id

\author{
Azhar Maksum \\ Department of Accounting \\ Universitas Sumatera Utara \\ Medan, Indonesia \\ azharmaksum16@usu.ac.id
}

\begin{abstract}
Research on the capital market in the tourism industry in Indonesia is still very limited, besides the results of research related to it each has not found consistent results. This research aims to assess empirically the antecedents of capital structure and its effect on firm value. The population of this study is a tourism industry sector in Indonesia listed on the Indonesia Stock Exchange active since 2007-2014 with sample research of 19 companies obtained by sampling total sampling technique. The variables analyzed in this study include profitability, growth Assets, capital structure and firm value. Hypothesis test using multiple linear regression analysis with data processing using SPSS program. The results show that profitability have a significant effect on capital structure whereas growth has no significant effect on capital structure. Profitability has significant effect to firm value, while growth and capital structure have no effect significant to firm value. While simultaneously variable profitability, growth, and capital structure have an effect on significant to firm value. Path analysis test shows that capital structure can't be an intervening variable that mediates the relationship between profitability with the firm value. But capital structure can be an intervening variable that mediates the relationship between Growth asset with the firm value
\end{abstract}

Keywords: profitability; Growth Asset; capital structure; firm value

\section{INTRODUCTION}

The tourism sector currently as leading sector after state revenue from tax sector. The tourism industry has a multiplier effect economic to another sector. The increase visit tourism has

\author{
Sirojuzilam \\ Department of Accounting \\ Universitas Sumatera Utara \\ Medan, Indonesia \\ sirojuzilam@usu.ac.id
}

wanted to the aviation industry, accommodation, souvenir, etc. The year 2016 total visitor of foreign tourist to Indonesia as 11, 5 million and foreign exchange earned from tourism sector as Rp 185 trillion [1]

So how about a tourism industry specific for the capital market. Currently, in Indonesian Capital Market as Bursa Efek Indonesia (BEI), there are as many 20th company wichs listed at BEI. This amount has increased from $67 \%$ between at 2003 when that currently wich as the 13th company. The investment in this sector in 2016 as $\mathrm{Rp} 15$ trillion from the foreign investor as $\mathrm{Rp} 12,8$ trillion and $\mathrm{Rp} 2,2$ trillion from domestic investment[1]

The establishment of a company has several goals, according to [2] there are three objectives of the establishment of a company by investors, among others: obtain maximum profit, prosper the owner and maximize the firm value. The Firm value as a condition achieved by the company after going through the process of activities for several years. With the looking at the ability of the company in obtaining the return then investor's expectations will be greater so it will motivate to invest. Investor delegates to the manager for manage the company to maximize the return and value of the firm (agency theory). So as a consequence will the agency cost for the investor's interest can be accommodated by the manager.

Profitability as a form the manager be able that performance has been achieved and profitability as the signal from company to investor so that investor's feel confident will get 
the return on the investment done. Profitability has a positive signal to the investor because the higher of profitability will give a great return to investors. So increased the profits will be an increase of investor confidence a potential investor to enable stock price and so that the firm value will also be increased.

Besides profitability, growth asset has an effect on the firm value. The greater company with the large assets will be easy to get credit from the creditor's so the company's financing needs will be easy, but the capital from the external financing will be at risk of adding a cost of capital as the loan interest. Therefore the company must be able to maintain the balance of capital structure in the optimal position. The optimal capital structure is when the benefit from the loan is greater than the cost incurred to external financing.

The firm value is a certain condition that has been achieved by a company as a picture of public confidence in the company after through a process of activity for several years, i.e. since the company was established until now. Investors' expectations of their investment are to obtain the maximum return with a certain risk. This expectation will actually happen if the investor has a very good ability in assessing the company's performance and sensitive to the financial condition of a country and the global economy. Investors 'and prospective investors' confidence in the prospect of the company has significance for the issuer, the more potential investors who believe in the issuer the desire to invest in the issuer is expected to increase

\section{LITERATURE REVIEW}

\section{A. Theory of the firm}

The company is an organization that organizes multiple sources for the purpose of making a profit [3]. Theory of the firm acknowledges profit maximization as the main target of the firm, the first has short-term profit target than for a long-term maximization of the existence of the company not only benefits the owner/shareholder but also expected to benefit the wider community, the government through the process of the economic activity.

\section{B. Agency theory}

Agency theory proposed by Jensen and Mecklin described the relationship between shareholder as principal and manager as an agent [4].To manage the company owner/shareholder no longer do it alone, they delegate it to a more professional manager in running the company. This theory suggests that there exists an optimal level in capital structure than can minimize the agency costs. The debt would be used as a controlling device to motivate managers to distribute free cash among shareholders instead of wasting it on inefficient activities. In carrying out its activities the agent must be able to make the best decision for the principal.

Principals and agents may have different goals so that an agency conflict will arise. Agency conflict will arise when a manager in making a decision does not match the goals of the shareholder regarding maximizing the prosperity of them. To be able to accommodate the interests of principals and the interests of agents it appears the agency costs as a supervision of principals to agents. If both parties can have the same vision to maximize the firm value then it is believed the agent will act in accordance with its principal interests. There are several ways to reduce agency conflict (Bathala et.al (1994):1) to increase ownership by management (Insider ownership) so that agents will act in accordance with the wishes of the principal as well as shareholders and will be motivated to improve performance and response to improve the prosperity of the company. 2) increase dividend ratio to net income. Dividends are the returns earned principal, the higher the dividend ratio of net income earned will increase the prosperity of shareholder. 3) increasing the source of funding through debt, increasing debt in the capital structure will reduce the use of stocks so as to reduce the cost of the equity agency, but the debt is too large will also impact bankruptcy risks caused by the repayment of loans and interest expenses 4) Institutional ownership by the institution. The institution as principal is a source of power that can be used to support or challenge management, therefore the concentration of institutional ownership will be a power in managers' control.

\section{Signaling Theory}

The signal is an action taken by the company to provide information/direction to investors about how management views the prospect of the company. [6] This theory states that investors believe higher levels of debt will imply higher quality and higher future cash flows. This means that lower quality firms with higher expected costs of bankruptcy at any level of debt cannot follow the steps of higher quality firms by incurring more debt. Such information is important for investors and other business actors as a basis for them in making investment decisions. The quality of investor decisions is influenced by the quality of information disclosed by the company on the financial statements it presents.

Signaling theory can help principals and other stakeholders in reducing information asymmetry because managers have more information related 
to the company than with principal or external parties. Asymmetric information according to [5] is a situation in which managers have different (better) information about the prospect of the firm than the investor have it.

\section{Pecking Order Theory}

This theory was first introduced by Donaldson [7] while names packing order theory was done by Myers [8].This theory is rooted on the notion of asymmetric information that corporate managers know more about their company's prospects, risk and value than do outside investors[4].. According to the theory, companies prefer to finance their projects from internally generated cash flows. When this is exhausted, debt will be used and when debt is exhausted, additional equity will be issued. DeAngelo and Masulis emphasized that each firm has an internal optimal capital structure that maximizes its value. This theory states that: (a) The company likes internal financing, (b) If external financing is required, the firm will issue the safest securities first, it starting with the issuance of bonds, then followed by a securities with optional characteristics (such as convertible bonds), only when insufficient, new shares are issued. In accordance with this theory, there is no target debt to equity ratio.

\section{E. Trade-off Theory}

The trade-off theory disclosed by Myers [8] states that the company will up to certain debt levels, where tax shields from additional debt equal the cost of financial distress. Financial distress costs are bankruptcy costs or reorganization, and agency costs are increased as a result of the credibility of a company. Trade-off theory in determining the optimal capital structure incorporates several factors including taxes, agency costs, and financial distress but retains market efficiency assumptions and asymmetric information as a counterweight to the benefits and uses of debt.

Optimum debt levels are achieved when tax shields reach the maximum amount of the cost of financial distress. Trade-off theory has implications that managers will think within the framework of a trade-off between tax savings and financial difficulties in determining the capital structure. Companies with high levels of profitability will certainly try to reduce taxes by increasing the ratio of debt, so the additional debt will reduce taxes.

\section{F. The Firm Value}

The firm value can be interpreted as the perception of investors to the success rate of companies there are often related to stock prices, where high stock prices will make the company's value is also high[10].Firms with high future growth opportunities are expected to use more equity financing because a highly leveraged company may forgo profitable investmentopportunities when it expects by undertaking the new project the value goes to firm's existing debt holders [8]. The value of a company is a certain condition that has been achieved by a company as a picture of public confidence in the company after through a process of activity for several years, i.e. since the company was established until now.

For the shareholders and potential investors, the condition of achievement is needed as a basis for decision-making whether the investment has made progress, stagnation or setbacks. The value of the company will be reflected from its share price. The market price of the firm's stock formed between the buyer and the seller in the event of a transaction is called the market value of the firm, and the market price of the stock is considered to be a reflection of the true value of the firm's assets.

\section{G. Capital Structure}

Capital Structure is a comparison or balance of long-term funding of a company which is shown by comparison of long-term debt to own capital, [2] To meet the financing needs of the company can be selected alternative sources of funds from internal and external. Internal funds can be obtained from share capital and retained earnings, while external funds are obtained from debt. The funding should be efficient which in turn can make the optimal capital structure. An optimal capital structure can be interpreted as a capital structure that can minimize the cost of capital use so that will maximize the value of the company. Capital Structure is a comparison or balance of long-term funding of a company which is shown by comparison of long-term debt to own capital, [2] To meet the financing needs of the company can be selected alternative sources of funds from internal and external. Internal funds can be obtained from share capital and retained earnings, while external funds are obtained from debt. The funding should be efficient which in turn can make the optimal capital structure. Optimal capital structure can be interpreted as a capital structure that can minimize the cost of capital use so that will maximize the value of the company

\section{H. Profitability}

One of the main objectives of the company is to seek profit or profit.Kemampuan companies in generating profit (profitability) are also one-factor company valuation, as stated by Ang that profitability affects the value of the company positively because the profitability ratio indicates the successful companies in generating 
profits[11].. If the profitability of the company is good then the creditors, suppliers, and investors who are stakeholders of the company will assess the company's performance properly.

\section{Growth Asset}

The growth of the company is an increase in corporate activity at the present time compared with the previous year. Companies that have rapid growth often have to increase their fixed assets. Thus, firms with high growth rates need more funds in the future and also hold more profits. Retained earnings from firms with high growth rates will increase, and those companies will be more in debt to maintain their targeted debt ratio [12]. The growth of the company is the hope of the internal and external parties of the company, the company's growth is expected to provide a positive signal the opportunity to invest.

Influence of profitability and growth of the company to capital structure.Every company has been expectation profit in its business, profitability ability will be an important factor in funding the company. Profitability affects the capital structure, the higher the profit of a company the more it will decrease its debt because of the more internal funds available to fund its investment [13].Companies with high rates of return on investment use relatively small debt. High returns make it possible to finance most of the funding needs with internally generated funds. The greater the level of profitability the smaller the ratio of capital structure. Therefore profitability has a negative effect on capital structure. Growth opportunity is a growth of a company in the future [12].Companies with high asset growth rates need more funds in the future. Based on the trade-off theory of firms with high levels of profits will be more debt to finance the activities of the company and to maintain the targeted debt ratio [12]. Increased assets followed by increased operating results will further increase the confidence of outsiders of the company. With the increasing trust of outsiders (creditors) to the company, the proportion of debt is greater than the capital itself.

The effect profitability and growth to firm value through a capital structure.

Profitability is the company's ability to generate profits and measure the level of operational efficiency and using its assets [14].This ability will certainly be one of the factors considered in the assessment of the company. Companies that have large profitability every year tend to be interested in investors. These investors consider a company whose big profit will generate a large return.

Investors and potential investors will judge the company positively if the profitability ratios show a positive trend, showing the company's better prospects and will be caught by investors as a positive signal from the company. Increasing the demand for a company's stock will indirectly raise the stock price in the stock market. The result of Septiono [1].Sstudy stated that profitability is a significant influence and positive relation to the variable of company value.

Another factor we have can also affect the value of the company is the growth The growth of the company is an increase in corporate activity at the present time compared with the previous year. Increased assets can increase investor confidence in the company because investors believe that the funds embedded in the company are guaranteed by a number of assets owned by the company. The company's assets have an important role to finance the company's operations. Therefore, an increase in the number of company assets used to finance the company's operations is expected to increase the company's ability to generate profits for the company.

In the effort to generate a maximum return, the company needs sufficient funding to support its operations. The amount of capital structure is an important thing that must be considered by the company because the good, bad capital structure will have a direct effect on the financial position of the company that will ultimately affect the value of the company. Therefore, in the utilization must be efficient so that it can make it more optimal. The optimal capital structure is a capital structure that can minimize average capital cost and maximize firm value. Capital structure is believed to be able to mediate from profitability and growth with firm value.

\section{J. Variables}

The variable used this research is the Profitability wich proxied with the return on equity (ROE), growth wich is proxied with the growth asset (GA), capital structure wich is proxied with the debt-asset ratio (DAR) and firm value wich is proxied with the price.

Define of variable as following :

Profitability (ROE) is the profit or rate of return on the owner's equity (Brigham, 2006)

Growth (GA) is the percentage increase or decrease in assets from the previous period to the next period, (Weston \& Coplan, 2009).

Capital structure (DAR) is a long-term debt and equity (Van Horne, 1995)

Firm value is the stock price at the time of closing price (Brigham, 2006)

\section{METHODOLOGY}

This research was conducted in the tourism industry sector which listed on Bursa Effect Initial Market Directory (ICMD) 2007 until 2014 in the form of annual report. There are 20 companies in the population and the whole 
company is sampled by sampling using the Total Sampling method. Of the 20 companies, only 19 companies are sampled because there is one company, PT Bukit Uluwatu Villa (BUVA) which is not eligible because of the new listing in IDX in 2010.

For the test influence of independent variable to dependent variable used the multiple regression with the equation as follows :

$Y_{1}=a+b_{1} X_{1}+b_{2} X_{2}+e$

$Y_{2}=a+b_{1} X_{1}+b_{2} X_{2}+b_{3} Y_{1}+e(2)$

Structural model of path analysis of the above description can be seen as follows :

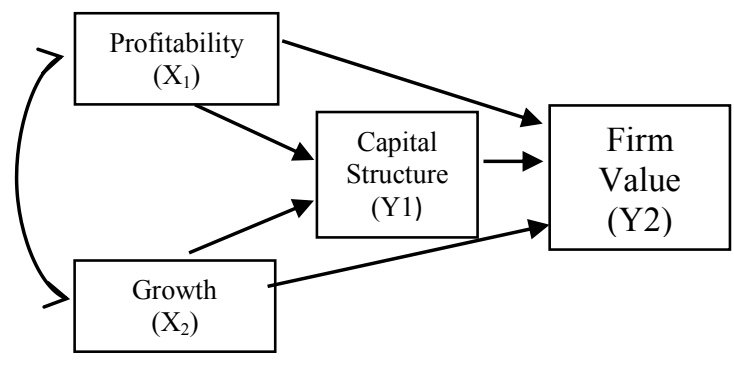

Figure.1 Model of path analysis

IV. DATA ANALYSIS AND RESULT

The results of hypothesis testing Fisthypothesis with the above equation model obtained the results as follows:

\begin{tabular}{|c|c|c|c|c|c|c|}
\hline \multicolumn{7}{|c|}{ Table 1. Coefficients Fist Hypothesis } \\
\hline \multirow{2}{*}{\multicolumn{2}{|c|}{ Model }} & \multicolumn{2}{|c|}{$\begin{array}{c}\text { Unstandardized } \\
\text { Coefficients }\end{array}$} & \multirow{2}{*}{\begin{tabular}{|c}
$\begin{array}{c}\text { Std. } \\
\text { Coefficients }\end{array}$ \\
Beta
\end{tabular}} & \multirow[t]{2}{*}{$\mathrm{t}$} & \multirow[t]{2}{*}{ Sig. } \\
\hline & & $\mathrm{B}$ & Std. Error & & & \\
\hline \multirow{3}{*}{1} & $\begin{array}{c}\text { (Cons } \\
\operatorname{tant}) \\
\end{array}$ & .408 & .021 & & 19.016 & .000 \\
\hline & $\mathrm{X}_{1}$ & .004 & .002 & .193 & 2.375 & .019 \\
\hline & $\mathrm{X}_{2}$ & .000 & .001 & .043 & .530 & .597 \\
\hline
\end{tabular}

Source: results of data processing (2015)

From the Table 1 up there showed coefficients reggressionas :

$$
\mathrm{Y}_{1}=0.408 \mathrm{a}+0.004 \mathrm{X}_{1}+0.000 \mathrm{X}_{2}+\mathrm{e}
$$

The partial test had results profitability a significant effect on the capital structure while growth has not significant effect on capital structure.
Table 2. Coefficients Second Hypothesis

\begin{tabular}{|c|c|c|c|c|c|c|}
\hline \multirow{2}{*}{\multicolumn{2}{|c|}{ Model }} & \multicolumn{2}{|c|}{$\begin{array}{c}\text { Unstandardized } \\
\text { Coefficients }\end{array}$} & \multirow{2}{*}{\begin{tabular}{|c|}
$\begin{array}{c}\text { Std. } \\
\text { Coefficients }\end{array}$ \\
Beta \\
\end{tabular}} & \multirow[t]{2}{*}{$\mathrm{t}$} & \multirow[t]{2}{*}{ Sig. } \\
\hline & & $\mathrm{B}$ & Std. Error & & & \\
\hline \multirow{4}{*}{1} & $\begin{array}{l}\text { (Con } \\
\text { stant) }\end{array}$ & 299.748 & 49.215 & & 6.091 & .000 \\
\hline & $\mathrm{X}_{1}$ & 10.764 & 2.046 & .399 & 5.260 & .000 \\
\hline & $\mathrm{X}_{2}$ & .622 & 1.052 & .044 & .592 & .555 \\
\hline & $Y_{1}$ & 158.631 & 101.513 & .117 & 1.563 & .120 \\
\hline \multicolumn{6}{|c|}{ a. Dependent Variable: Price } & \\
\hline
\end{tabular}

Source: results of data processing (2015)

From the Table 2 showed coefficients reggressionas :

$$
\begin{gathered}
Y_{2}=-299.748 a+10.764 X_{1}+0.622 X_{2} \\
+158.631 Y_{1}+e
\end{gathered}
$$

The partial test had results Profitability a significant effect on firm value, while growth and capital structure have not significant effect on firm value.

\begin{tabular}{|c|c|c|c|}
\hline Table 3. Correlations \\
\hline Variable & $\begin{array}{c}\text { Direct } \\
\text { Effect }\end{array}$ & $\begin{array}{c}\text { Total } \\
\text { Effect }\end{array}$ & Remark \\
\hline ROE to Price & 0.429 & 0.259 & $\begin{array}{c}\text { Not } \\
\text { Mediated }\end{array}$ \\
\hline GA to Price & 0.111 & 0.272 & Mediated \\
\hline
\end{tabular}
Correlation is significant at the 0.05 level (2-tailed).
Source: results of data processing (2015)

The path analysis test showed that: The direct effect profitability to firm value is 0.428 while total effect profitability through capital structure 0.259 but direct effect is bigger from total effect $(0.428>0.259)$ so that capital structure had can't the variable intervening wich mediates relationships profitability to firm value. Then direct effect Growth to firm value is 0.111 while total effect growth to firm value through capital structure 0.272 so that capital structure had can the variable intervening wich mediates relationships growth to firm value because total effect growth to firm value through the capital structure is bigger from direct effect growth to firm value. 


\section{CONCLUSION}

This research has examined the capital structure and firm value of the profitability and growth the effect. The result obtained from this research suggest that: The profitability a significant effect on the capital structure while growth has not significant effect on capital structure.Profitability a significant effect on firm value, while growth and capital structure have not significant effect on firm value.The capital structure had can't the variable intervening wich mediates relationships profitability to firm value.Capital structure had can the variable intervening wich mediates relationships growth to firm value

\section{REFERENCES}

.11] Kemenpar, 2016, Laporan kinerja instansi pemerintah (Lakip), Kementerian Pariwisata Republik Indonesia, Jakarta

[2] Martono \& Harjito, 2008, Manajemen Keuangan, Cetakan ketujuh, Yogjakarta, Ekonesia.

[3] Modigliani, $\mathrm{F}$ and Miller, $\mathrm{M} \mathrm{H}$ (1958)."The Cost of Capital, Corporation Finance and the Theory of Investment," American Economic Review, 48, pp 26197.

[4]. Jensen, $M$ and Meckling, W (1976). "Theory of the Firm: Managerial Behaviour, Agency Costs and Ownership Structure," Journal of Financial Economics, 3,pp 305-60.

[5] Brigham, Eugene, F dan L.C Gapenski, 1993, Intermediate Financial. Management, Fourth, Fort Word, The Dyrden Press,: Harcourt Brace. College Publisher.

[6] Brigham dan Houston, 2006.

Fundamentals Of Financial Managament, Dasar-. Dasar Manajamen Keuangan. Edisi 10, Buku 1. Jakarta: Salemba Empat.

[7] Donaldson G. (1961), Corporate debt capacity: A study of corporate debt policy and the determination of corporate debt capacity, Boston division of Research, Harvard Graduate School Of Business Administration.

[8] Myers C.S. (1984), "The capital structure puzzle", The Journal of Finance, vol 39, No. 3 (July 1984), p.p. $575-592$

[9] Masulis, M S (1983)."The Impact of Capital Structure on Firm Value," Journal of Finance, 38, pp 107-25.

[10]. Van Horne, James C. and John M. Wachowicz, Jr., 1998, Fundamental Of
Financial Management, Tenth edition, Prentice Hall International, Inc. New Jersey

[11]. Ang, Robert, 1997, Buku Pintar Modal Indonesia, The Intelegent Guide to Indonesian Capital Market, Mediashoft Indonesia, Jakarta,

[12]. Muhammad Umar Mai, 2006, Analisis variabel-variabel yang mempengaruhi strutur Modal pada Perusahaan-perusahaan LQ 45 di Bursa efek Jakarta, Juernal Ekonomika, Politeknik Bandung, Hal. 228-245.

[13]. Brigham, F. Eugene dan Houston, Joel F. 2001. Manajemen Keuangan. Diterjemahkan oleh Dodo Suharto dan Herman Wibowo. Edisi Kedelapan. Jakarta : Erlangga

[14]. Chen, 2004). Strategic purchasing, supply management, and firm performance Journal of Operations Management 22 (2004) 505-523 